\title{
Synthesis and Theoretical Study of new Schiff base derivatives
}

\author{
Leaqaa A. AL-Rubaie* Hanoy K. Al-Amood** Rafeef A. Al-Sammarai*** \\ *Department of pharmaceutical chemistry. Pharmacy college \\ **Department of chemistry-Science college \\ ***Department of Biochemistry. Pharmacy college \\ *leaqaa2000@yahoo.com
}

\section{$\underline{\text { Abstract }}$}

The study include preparation two Schiff base compounds, 4-acetoamidobenzylidine-glycine SB-A and 4acetoamidobenzylidine -nitrourea SB-B . Schiff bases were prepared by condensation of 4-acetanilbenzaldehyde with nitrourea and other with glycin. The products were characterized by both FT- IR and UV-Vis. Spectroscopyphotometry. The biological activities against selected types of bacteria which included gram positive bacteria (staphylococcus aureus), and gram negative bacteria (Escherichia coli, proteus sp., pseudomonas aeruginosa) was studied. Later, theoretical studies by using the optimized geometry molecular structures of both compounds, indicates SB-B is more stable than SB-A.

Key words: p-acetamidobenzaldehyde, glycin Schiff base, nitrourea derivatives

الخلاصة

تتضمن الدراسة تحضير مركبين من صنف قواعد شف ع ع- اسيتاميدو بنزايليدين-كلايسين SB-B. و والآخر ع ع- اسيتاميدو بنزايليدين-

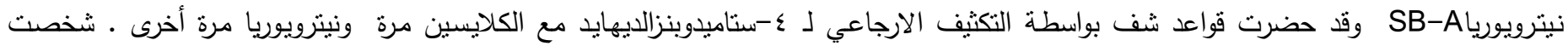

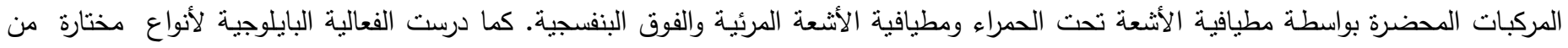

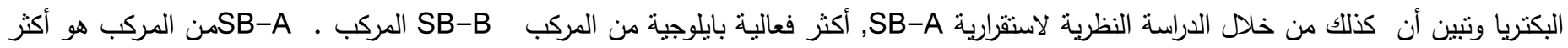

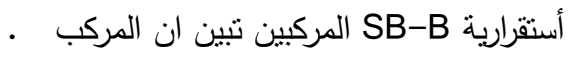

\section{1-Introduction:}

Compounds containing an azomethine group $(-\mathrm{C}=\mathrm{N}-)$ are known as Schiff bases ${ }^{(1)}$. They are usually formed by condensation of a primary amine with a carbonyl compound according to the following scheme :

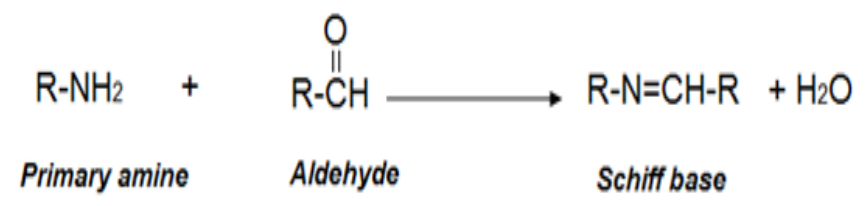

where $\mathrm{R}$ may be an aliphatic or an aromatic group. Schiff base compounds have been used as fine chemicals and medicals substrates ${ }^{(2)}$. A Schiff base derived from an aniline, where $\mathrm{R}$ is a phenyl or a substituted phenyl, can be called an anil ${ }^{(3)}$. Bulter and Hussain reported the reaction of benzaldehyde and substituted benzaldehydes with urea, thiourea and their alkyl/ aryl derivatives in acid media ${ }^{(4)}$. The reaction of urea with benzaldehyde was first reported by Schiff (5 ) . Hussain reported Schiff bases products from reaction of p-dimethylaminobenzaldehyde with urea, thiourea and their alkyl/aryl derivatives $(6$ ) .Subsequently, Schiff base products was prepared from reaction of 4-N,N-dimethylamino- cinnamaldehyde with urea, thiourea and their derivatives in acid media(7).Schiff base also have biological importance. An imine linkage between the aldehyde derived from vitamin A and the protein opsin in the retina of the eye plays an important role in the chemistry of vision. Vitamins are also called coenzymes, meaning that they are to the functioning of many enzymes, which are large proteins that catalyze chemical changes in cell (8). Schiff bases have been reported in their biological properties, such as, Schiff bases have also been shown to exhibit a broad range of biological activities, including antifungal(9), antibacterial(10), analgesic(11) , anti-tubercular(12), anti-inflammatory(13), antiviral, antipyretic properties $(14,15)$, antioxidant (16) and enzyme inhibitors(17) . They also exhibit significant anticonvulsant activity(18) and antitumor activity(19). Schiff $\mathrm{s}$ base complexes play an important role in 
designing metal complexes related to synthetic and natural oxygen carriers(20) .The main aim of the research is synthesis and characterization of Schiff bases with different in amine side chain (glycin and nitrourea) ,also compare between its biological against microorganisms.

\section{2-Expermental:}

\section{1- Instrumentals:}

Melting points were measured on Stuart SMP3. The FT-IR spectra ( $\mathrm{KBr}$ disk) were recorded on Shimadzu spectrophotometer in the rang $400-4000 \mathrm{~cm}^{-}$ 1 , While the U.V. Vis. spectra are measured with UV1100 spectrophotometer in $\mathrm{CHCl}_{3}$.

\section{2- Chemicals:}

All chemicals and solvents were supplied from Aldrich and Merck chemical companies.

\section{3- Methods:}

\subsection{1- Preparation of urea nitrate (21):}

Conc. $\mathrm{HNO}_{3}(10.8 \mathrm{ml})$ and $8 \mathrm{~g}(0.1 \mathrm{mmole})$ of urea (dissolved in $12 \mathrm{ml} \mathrm{H}_{2} \mathrm{O}$ ) in a $50 \mathrm{ml}$ round-bottomed flask, was stirred at room temperature for 2 hours. The precipitate was filtered and the product is washed with four portions cold water and a white crystalline solid of urea nitrate $\left(\mathrm{NH}_{2} \mathrm{CONH}_{2} \quad . \mathrm{HNO}_{3}\right)$ was obtained (m.p.162- $163^{\circ} \mathrm{C}$ ).

\subsection{2- Preparation of nitro urea $(22)$ :}

Conc. sulfuric acid $(14 \mathrm{ml})$ was cooled to $-3{ }^{\circ} \mathrm{C}$ in ice bath , $4 \mathrm{gm}(0.038 \mathrm{mmol})$ dry powdered of urea nitrate was added by fraction to control the temperature below $0{ }^{\circ} \mathrm{C}$. The mixture is poured upon crushed ice, the white divided finally precipitate of nitrourea is form. The product is washed with 4 portions of cold water (m.p. 157-159 ${ }^{\circ} \mathrm{C}$ ).

\section{3- Preparation of 4-Acetoaminobenzylidene-} glycin Schiff base (SB-A) ${ }^{(23)}$ :

4-acetoaminebenzaldehyde $0.163 \mathrm{~g}(1 \mathrm{mmol})$ and $0.075 \mathrm{~g}$ (1mmol) of glycin were dissolved in $10 \mathrm{ml}$ $95 \%$ ethanol in a $50 \mathrm{ml}$ round bottom flask. $0.5 \mathrm{ml}$ of $10 \%$ w/v NaOH were added to the solution and reflux for six hours with stirring. The solution of light yellow colour was then filtered off and the product was recrystallized in methanol (m.p. $127-128^{\circ} \mathrm{C}$ ) figure (1).

\section{4- Preparation of 4-Acetoaminobenzylidene-} nitrourea Schiff base (SB-B):

4-acetoaminebenzaldehyde $0.163 \mathrm{~g},(1 \mathrm{mmol})$ and 0.105 $\mathrm{g}(1 \mathrm{mmol})$ of nitro urea were dissolved in $10 \mathrm{ml} 95 \%$ ethanol . $0.5 \mathrm{ml}$ of $10 \% \mathrm{NaOH}$ were added and allowed to reflux for three hours in an isomental with stirring. The red colour precipitate was then filtered off and then recrystallized in a mixture of acetone and ethylacetate (1:1)( decomposed at m.p. $220-222^{\circ} \mathrm{C}$ ) figure (1).

\section{Results and Discussion:}

The two derivatives of 4-acetoamine benzaldehyde with glycin and nitrourea as Schiff base compounds were prepared figure (1). The FT-IR spectra of both Schiff base was showed characteristic functional groups as shows in table (1). FT-IR spectra bands of acetoaminobenzylidene-glycin Schiff base (SB-A) showed strong peak at $1658.67 \mathrm{~cm}^{-1}$ which corresponding to carbonyl group of side chain $\left(\mathrm{CH}_{3} \mathrm{CONH}-{ }^{-}\right)$band. The band at $1608.52 \mathrm{~cm}^{-1}$ confirmed the presence of $(-\mathrm{C}=\mathrm{N}-)$ which is the characteristic of Schiff base. While acetoaminobenzylidene- nitrourea Schiff base (SB-B), appearance $(-\mathrm{C}=\mathrm{N}-)$ band at $1630 \mathrm{~cm}^{-1}$ and carbonyl group in $\left(\mathrm{CH}_{3} \mathrm{CONH}-\right)$ at $1655 \mathrm{~cm}^{-1}$.From UV-Vis. spectra of both SB-A and SB-B have been studied in chloroform $\left(\mathrm{CHCl}_{3}\right)$. The maximum absorption wavelengths for both compounds are shown in table (2) .Shift band of compound SB-B is greater than compound SB-A. The enhanced shifting is due to increasing resonnance interaction in compound SB-B figure ( 3) .

\section{Antibacterial activity:}

The method agar diffusion was used to estimate the biological activity ${ }^{(24)}$.The biological activity of both compounds was studied against selected types of bacteria which included gram positive bacteria (staphylococcus aureus), and gram negative bacteria (Escherichia coli, proteus sp.,pseudomonas aeruginosa) in nutrient agar media, which is used DMSO as a solvent and as a control for the disc sensitivity test. the results of biological activity in table(3).Compounds SB-A, found have inhibition zone against S.aureus with less inhibition against E.coli but Compound SB-B more inhibition zone against both the same species. The result was not surprising for SB-B compound, because it contain nitrourea part, which has a pronounced effect on the growth of E.Coli. It is apparent that significant inhibition of growth ${ }^{(25)}$. The result of antibacterial activity study for Schiff base exhibited antibacterial activity against the studied bacteria . The increased activity of the synthesized compound can be explained electron delocalization over the whole molecule figure( 3 ). This increases the lipophilic character of the molecule and favors its permeation through the lipoid layer of the bacterial membranes. The increased lipophilic character of this molecule 
seems to be responsible for it enhanced potent antibacterial activity ${ }^{(9)}$. Physical properties calculations of both compounds SB-A \& SB-B, figure (4) was done using the optimized geometry molecular structures of both compounds ${ }^{(26)}$. Molecular orbital calculations provide a detailed description of orbital's including the energy of highest occupied molecular orbital (HOMO) of compound (SB-A) is $-8.724483 \mathrm{ev}$ whereas the energy of lowest unoccupied molecular orbital (LUMO) is $-0.4674064 \mathrm{ev}$.The high value in the HOMO and LUMO energy gap explains no eventual charge transfer interaction taking place within the molecules. The same results to compound (SB-B), whereas the energy for orbital's (HOMO) and (LUMO) are - $0.9128115 \mathrm{ev}$, $0.1297816 \mathrm{ev}$. respectively. Other physical data in table (4). From $\log \mathrm{p}$ values (indicate the hydrophobicity properties) ,compound (SB-B) is more lipophilic properties, while compound (SB-A) is more hydrophilic characteristic. Heat of formation of compound(SB-B) less than (SB-A), from total energy values, indicates the compound (SB-B) more stable.By above results, in addition to the surface area for compound (SB-B), is great make it more binding with the receptor, also its small volume can pass easily through pores that confirme with antibacterial activity that result, more penetration cell.Larg dipole moment $(\mu)$ of compound SB-B, because the $\mathrm{NO}_{2}$ group plays an important role in theproperty for this compound.We suggest the mechanism of action for Schiff base SB-B may like alkylating agent nitroso urea .

\section{References:}

1- S. Kalaivani, N. Padma Priya and S. Arunachalam, IJABPT, (2012) 3, 219-223.

2- A. Asiri, A. Al-Yobi, S. Khan, M. Tahir, Acta Cryst. Sect. E (2011), 67(pt 12),1570-1574.

3- A. Al-Amiery, Y. K. Al-Majedy, H. H. Ibrahim and A.A . Al-Tamimi , Org.Med. Chem. Lett. (2010) $3,7$.

4- A.R.Butler and I.Hussain , J.Chem.Res.(1994) 03(M), 6261.

5 -H. Schiff, Ann.Chem. (1869) 151,186.

6- Y.Ogata, A.Kawaski and N.Okumura, Tetrahedron (1966) 22,1731.

7- I.Hussain and U.Shaukat, J. Chem .Soc. Pak. (2002) 24,4 .

8- M. A.Ashraf, K. Mahmood, A. Wajid, IPCBEE (2011) 10 .

9-Sengupta A K ,Sen S, Srivastava V , J Ind. Chem. Soc. (1989) 66, 710.
10- A. Al-Amiery, Y. K. Al-Majedy, H. H. Ibrahim and A.A . Al-Tamimi , Org.Med. Chem. Lett. (2012) 2, 4.

11-.A. Rashmi et al. , IRJP ( 2012), 3 , 7.

12- N. Sinha, S.Jain, A.Tilekar S.K.Arora, Bioorg. Med.Chem. Lett. (2005) $15,1573$.

13- B.Narayana , B.V.Ashlatha, K.K.Vijaya and N.S.Kumari, Ind. J. Chem. (2006) 45 B, 26962703.

14- D.N. Dhar and C.L. Taploo, J. Sci. Ind. Res. (1982) 41, 501.

15- P. Przybylski, A. Huczynski, K. Pyta, and B. Bartl, Curr. Org. Chem.(2009) 13, 124.

16- L.Cheng ,J. Tang, H. Luo , X. Jin , F. Dai , J. Yang , Y. Qian, X. Li and B. Zhou, Bioorg.

Med. Chem. Lett. (2010) 20, 2417.

17- K.M.Khan, N.Ambreen, S. Hussain, S. Perveen and M. I.Choudhary.; Bioorg.Med. Chem.

(2009)17, 2983.

18- N.S.Pandeya and N. Rajput, IJMC (2012)10, 1155.

19- R.Nirmal,C.R. Prakash, K. Meenakshi, and P. Shanmugapandiyan, J Young Pharm. (2010) 2(2), 162 .

20- K. Mounika, B. Anupama, J. Pragathi, and C. Gyanakumari, J.Sci.Res.(2010) 2(3), 513.

21- Organic syntheses, coll.vol.1,p.417(1941)

22- H.Gilman and C.C. Vernon, Organic Synthesis, Coll. (1941)1,417.

23- A.S.P.Azzouz and R.T.Ali, N.J.C.(2010) 37,158168.

24- Jawetz, Midical Microbiology, Melnick and Adeibergs, U.N. 1998.

25 - I.M.Klotz and M. Mellody, (1949), J.Bacteriol., 57(5), 477.

26- Hyperchem for windows, copyright by Hypercub, Inc., publication 2000

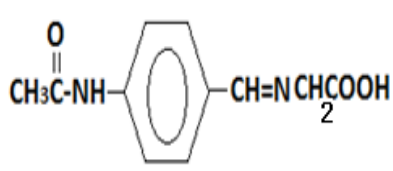

SB-A

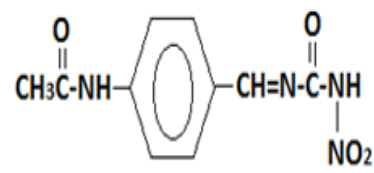

SB-B
Figure (1) :Chemical structure of compounds 
Table (1):The characteristic FT-IR spectra bands in both compounds

\begin{tabular}{|c|c|c|}
\hline Streaching vibration & SB-A & SB-B \\
\hline$v(-\mathrm{C}=\mathrm{N})$ & 1608.52 & 1630 \\
\hline U NO2 streaching & - & asy. 1550, sym. $=1310$ \\
\hline$V_{\mathrm{C}}=\mathrm{O}\left(\mathrm{CH}_{3} \mathrm{CO}-\mathrm{NH}-\right)$ & 1658.67 & 1655 \\
\hline V $\mathrm{C}=\mathrm{O} \quad$ (amino acid) & 1554.52 & \\
\hline V C=O (NO2-NH-CO-) & 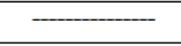 & 1695 \\
\hline$v$ (C-H) aliphatic & $\begin{array}{l}\text { Asym. 2933.53, } \\
\text { sym. } 2827.53\end{array}$ & $\begin{array}{c}\text { Asym. } 2925, \\
\text { sym. } \quad 2860\end{array}$ \\
\hline $\mathrm{V}(\mathrm{C}-\mathrm{H})$ aromatic & 3070.46 & 3100 \\
\hline$v(-\mathrm{OH}) \mathrm{COOH}$ & 3446.56 & - \\
\hline$v(-\mathrm{C}-\mathrm{N})$ & 835.12 & 830 \\
\hline
\end{tabular}

asym. $=$ asymmetry $\quad$ sym. $=$ symmetry

Table (2) : UV.Vis. spectra of both compounds

\begin{tabular}{|c|l|c|}
\hline Compounds & $\lambda$ max. $($ nm $)$ & Type of absorbtion \\
\hline SB-A & 290 & $n \rightarrow \pi^{*}$ \\
\hline SB-B & 315 & $n \rightarrow \pi^{*}$ \\
\hline
\end{tabular}<smiles>CC(=O)NCCNC(=O)C=C1C=CC2CCC1C2</smiles>

SB-A Compound

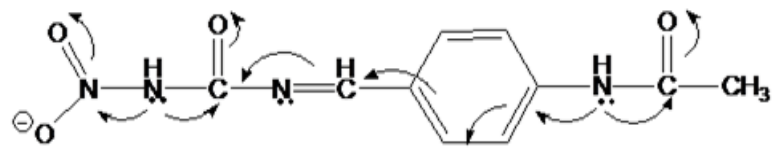

SB-B Compound

Figure (3): Electron delocalization of compounds SB-A and SB-B.

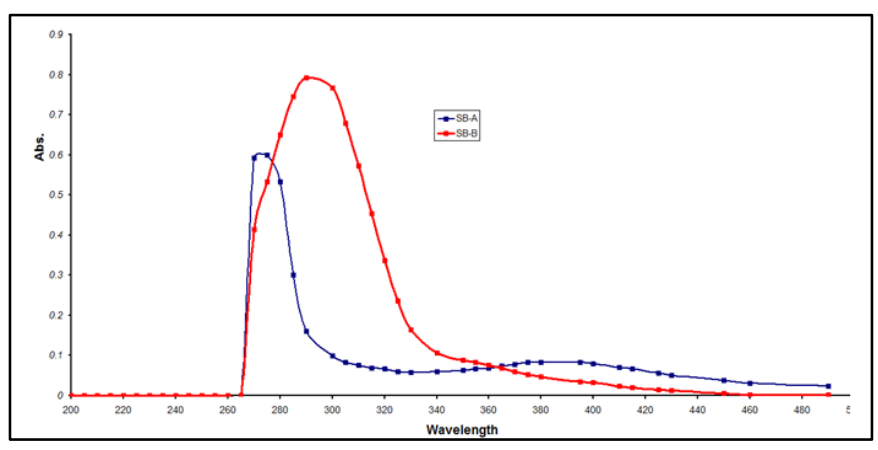

Figure (2): UV-Vis absorption
Table (3): The biological activity of compounds for several types of bacteria

\begin{tabular}{|c|c|c|c|c|}
\hline \multirow{2}{*}{ Compound } & \multicolumn{4}{|c|}{ Inhibition zone of clinical isolates } \\
\cline { 2 - 5 } & \multicolumn{3}{|c|}{ Gram negative bacteria } & Gram positive bacteria \\
\cline { 2 - 5 } & E.coli & P.aer. & Pr.sp. & S.aureus \\
\hline SB-A & $0.65 \mathrm{~mm}$ & Zero & Zero & $0.7 \mathrm{~mm}$ \\
\hline SB-B & $0.8 \mathrm{~mm}$ & Zero & Zero & $0.75 \mathrm{~mm}$ \\
\hline \hline
\end{tabular}

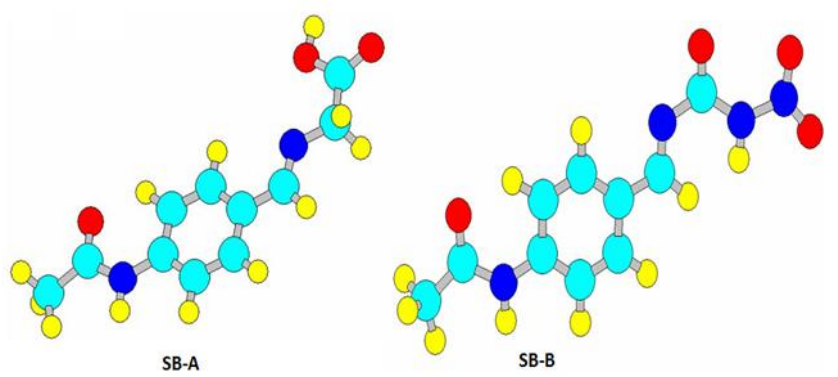

Figure (4): 3D structures of both SB-A and SB-B

Table (4): calculated Physical properties of prepared compounds

\begin{tabular}{|l|c|c|}
\hline \multicolumn{1}{|c|}{ Physical properties } & Compound SB-A & Compound SB-B \\
\hline Total energy & -62120.27 & -72835.83 \\
\hline Binding energy & -2999.701 & -2941.302 \\
\hline HOMO & $-8.724483 \mathrm{ev}$ & $-9.128115 \mathrm{ev}$ \\
\hline LUMO & $-0.4674064 \mathrm{ev}$ & $-1.297816 \mathrm{ev}$ \\
\hline Dipole moment & 6.027 (Debye) & $9.713 \quad$ (Debye) \\
\hline Heat of formation & -90.01006 & -21.14594 \\
\hline Surface area & $420.33[$ Approx] & $462.21[$ Approx] \\
\hline Volume & $639.86[$ grid] & 711.40 \\
\hline Hydration energy & 687.17 & $-16.53 \mathrm{kcal} / \mathrm{mol}$ \\
\hline Log p & $-9.18 \mathrm{kcal}$ mol & 6.11 \\
\hline Refractivity & 0.53 & 59.08 \\
\hline Polarizability & 58.77 & 23.42 \\
\hline \hline
\end{tabular}

